\title{
PENGARUH KARAKTER EKSEKUTIF, CAPITAL INTENSITY, DAN KEPEMILIKAN KELUARGA TERHADAP TAX AVOIDANCE (Studi Empiris Pada Perusahaan Makanan dan Minuman yang Terdaftar di Bursa Efek Indonesia Periode 2014-2018)
}

\section{THE EFFECT OF EXECUTIVE CHARACTER, CAPITAL INTENSITY, AND FAMILY OWNERSHIP ON TAX AVOIDANCE (An Empirical Study in Food and Beverages Company Listed in Indonesian Stock Exchange During 2014-2018)}

\author{
Rd. Mohd. Raditya Ekaputra Tj 1). Mohamad Rafki Nazar2), \\ Ardan Gani Asalam ${ }^{3)}$ dan Asmaul Husna1). \\ 1) , 2), 3)Telkom University, - Bandung \\ ${ }^{4}$ Universitas Maritim Raja Ali Haji,-- Tanjung Pinang \\ Email : mohdraditya@gmail.com
}

\begin{abstract}
ABSTRAK
Penelitian ini bertujuan untuk menguji bukti empiris baik secara simultan maupun secara parsial mengenai pengaruh karakter eksekutif, capital intensity, dan kepemilikan keluarga terhadap tax avoidance pada perusahaan subsektor makanan dan minuman yang terdaftar di Bursa Efek Indonesia periode 2014-2018. Penelitian ini terdiri dari 50 sampel perusahaan makanan dan minuman yang terdaftar di Bursa Efek Indonesia periode 2014-2018. Sampel diperoleh secara purposive sampling. Metode analisis yang digunakan dalam penelitian ini adalah analisis statistik deskriptif dan analisis regresi data panel dengan menggunakan Eviews 10. Hasil penelitian ini menunjukkan bahwa karakter eksekutif, capital intensity, dan kepemilikan keluarga berpengaruh secara simultan terhadap tax avoidance. Secara parsial, capital intensity dan kepemilikan keluarga berpengaruh terhadap tax avoidance. Sedangkan karakter eksekutif tidak berpengaruh terhadap tax avoidance.
\end{abstract}

Kata Kunci : Karakter Eksekutif, Capital Intensity, Kepemilikan Keluarga dan Tax Avoidance

\begin{abstract}
This study aims to examine empirical evidence both simultaneously and partially about the effect of executive character, capital intensity, and family ownership on tax avoidance in the food and beverage subsector companies listed on the Indonesia Stock Exchange period 2014-2018. This study consisted of 50 samples of food and beverage companies listed on the Indonesia Stock Exchange in the 2014-2018 period. Samples were obtained by purposive sampling. The analytical method used in this research is descriptive statistical analysis and panel data regression analysis using Eviews 10 . The results of this study indicate that the character of the executive, capital intensity, and family ownership simultaneously influence the tax avoidance. Partially, capital intensity and family ownership affect tax avoidance. While the executive character has no effect on tax avoidance.
\end{abstract}

Keywords: Executive Character, Capital Intensity, Family Ownership and Tax Avoidance 


\section{PENDAHULUAN}

Perkembangan ekonomi di Indonesia setiap tahunnya memerlukan dana yang besar untuk menunjang keberhasilan perekonomian nasional. Dana yang besar tentunya didapat berdasarkan target pendapatan negara setiap tahunnya. Menurut Kementerian Keuangan terdapat tiga sumber pendapatan negara yaitu dari sektor pajak, penerimaan negara bukan pajak (PNBP), dan hibah (APBN, 2018). Berdasarkan gambar 1.2 dari Kementerian Keuangan dalam penetapan Anggaran Pendapatan dan Belanja Negara (APBN), tercatat selama periode 2014 sampai 2018 penyumbang dana terbesar untuk pendapatan negara adalah dari sektor penerimaan pajak. Penerimaan pajak merupakan sumber pendapatan negara yang membiayai anggaran belanja negara yang nantinya akan meningkatkan pertumbuhan ekonomi nasional. Dalam hal ini, pemerintah wajib untuk menetapkan ataupun memperbaharui regulasi pajak agar dapat memaksimalkan potensi penerimaan pajak di Indonesia. Kementerian Keuangan mengungkapkan penerimaan pajak tahun 2018 mencapai Rp. 1.315,9 triliun, atau hanya 92\% realisasi dari target APBN 2018 sebesar Rp. 1.424 triliun. Artinya kekurangan penerimaan (shortfall) pajak sebesar Rp. 108,1 triliun tahun lalu. Menteri Keuangan juga menjelaskan seluruh angka dalam realisasi APBN, termasuk realisasi pajak masih bisa berubah hingga audit BPK (CNBC Indonesia).

Tax avoidance merupakan upaya penghindaran pajak dengan metode dan teknik yang digunakan cenderung memanfaatkan kelemahan-kelemahan (grey area) yang terdapat pada peraturan perundang-undangan mengenai perpajakan itu sendiri, untuk mengecilkan beban pajak terutangnya (Pohan, 2016:23). Tindakan tax avoidance merugikan pemerintah karena pemerintah tidak dapat mengoptimalisasikan penerimaan pajak (Nengsih, Suryani, \& Kurnia, 2018). Berdasarkan penjelasan tersebut, peneliti menyimpulkan bahwa tax avoidance akan mempengaruhi tinggi atau rendahnya tingkat penerimaan pajak negara.

Terdapat beberapa faktor yang mempengaruhi praktik tax avoidance. Faktor yang digunakan dalam penelitian ini adalah karakter eksekutif, capital intensity, dan kepemilikan keluarga.

\section{Tax Avoidance}

Tax avoidance adalah upaya penghindaran pajak yang dilakukan secara legal dan aman bagi Wajib Pajak karena tidak bertentangan dengan ketentuan perpajakan, di mana metode dan teknik yang digunakan cenderung memanfaatkan kelemahan-kelemahan (grey area) yang terdapat dalam undang-undang dan peraturan perpajakan itu sendiri, untuk memperkecil jumlah pajak yang terutang (Pohan, 2016:23). Pengukuran Tax Avoidance menggunakan Cash Effective Tax Ratio (CETR) karena mampu menggambarkan aktifitas tax avoidance yang berasal dari dampak perbedaan temporer dan perbedaan permanen (Chen, Chen, Cheng, \& Shevlin, 2010). Tax avoidance dirumuskan sebagai berikut:

$$
\text { CETR }=\frac{\text { Arus Kas Pajak }}{\text { Laba Sebelum Pajak }}
$$

\section{Karakter Eksekutif}

Eksekutif dalam melaksanakan kewajibannya sebagai pimpinan perusahaan mempunyai salah satu dari 2 karakteristik, yaitu sebagai risk taker atau risk averse (Low, 2006). Pimpinan dengan karakteristik sebagai risk taker (pengambil resiko) cenderung akan lebih berani untuk 
mengambil keputusan walaupun keputusan tersebut memiliki resiko yang tinggi dalam menjalankan bisnisnya. Sedangkan pimpinan dengan karakter risk averse (penghindar resiko) cenderung tidak menyukai resiko sehingga dalam pengambilan keputusan selalu memilih dengan resiko yang lebih rendah. Dalam penelitian ini, karakter eksekutif diukur dengan risiko perusahaan (corporate risk) dengan membagi hasil standar deviasi EBITDA (Earning Before Income Tax, Depreciation, and Amortization)dengan total aset perusahaan (Paligorova, 2010).

$$
\text { RISK }=\frac{\text { EBITDA }}{\text { TOTALASET }}
$$

Eksekutif yang memiliki corporate risk diatas nilai rata-rata akan diberi nilai 1 yang artinya eksekutif tersebut memiliki karakter risk taker. Eksekutif yang memiliki corporate risk dibawah nilai rata-rata akan diberi nilai 0 yang artinya eksekutif tersebut memiliki karakter risk averse.

\section{Capital Intensity}

Capital intensity dapat diidentifikasikan sebagai perusahaan yang menginvestasikan asetnya pada aset tetap dan persediaan (Rifka, 2016). Kepemilikan aset tetap yang besar dapat mengurangi pajak, karena aset tetap memiliki beban depresiasi atau beban penyusutan yang dapat dijadikan sebagai pengurang pajak (Anindyka S, Pratomo, \& Kurnia, 2018). Maka dari itu, beban depresiasi atas investasi pada aset tetap dapat mengurangi penghasilan kena pajak. Berikut merupakan rumus capital intensity:

$$
\text { Capital Intensity Ratio }=\frac{\text { Total Aset Tetap Bersih }}{\text { Total Aset }}
$$

\section{Kepemilikan Keluarga}

Family firm (perusahaan keluarga) adalah setiap perusahaan yang memiliki pemegang saham dominan (Anderson \& Reeb, 2003). Family business atau bisnis keluarga merupakan sebuah bisnis yang dikelola, dimiliki, dan dijalankan oleh sejumlah orang yang memiliki hubungan kekeluargaan, baik hubungan suami istri dan keturunannya, maupun hubungan persaudaraan (Asfiyati, 2012). Hak kontrol terhadap kepemilikan saham terbesar selaras dengan pembuatan kebijakan perusahaan serta pengambilan keputusan terhadap tujuan perusahaan yang akan dicapai. Maka dari itu, hak kontrol yang digunakan dalam hal ini adalah kepemilikan saham terbesar di perusahaan yang dapat dikatakan sebagai kepemilikan keluarga.

\section{Pengembangan Hipotesis \\ Pengaruh Karakter Eksekutif Terhadap Tax Avoidance}

Eksekutif yang memiliki karakteristik sebagai risk taker akan menggunakan kemampuannya untuk memaksimalkan laba perusahaan dengan mengambil keputusankeputusan yang berisiko. Risiko yang dapat diambil oleh eksekutif ini adalah dengan melakukan penghindaran pajak, karena dengan melakukan keputusan ini, eksekutif dengan karakter risk taker dapat meningkatkan laba perusahaan yang dipimpinnya. Hal ini sejalan dengan Alviyani (2016) yang menyebutkan bahwa eksekutif yang memiliki karakter risk taker akan cenderung mengambil keputusan yang berani dan lebih berisiko bagi perusahaan sehingga hasil yang didapat juga maksimal. Dengan demikian, dapat disimpulkan bahwa karakter eksekutif berpengaruh positif terhadap tax avoidance. Hal ini didukung oleh penelitian Alviyani (2016), Oktamawati (2017), dan Swingly \& Sukartha (2015) yang membuktikan bahwa semakin tinggi karakter risk taker eksekutif maka risiko akan berpengaruh positif terhadap tax avoidance. Maka 
peneliti menduga sementara bahwa karakter eksekutif berpengaruh positif terhadap tax avoidance.

H1 : Karakter Eksekutif secara parsial berpengaruh positif terhadap Tax Avoidance

\section{Pengaruh Capital Intensity Terhadap Tax Avoidance}

Capital intensity merupakan investasi pada perusahaan yang difokuskan pada aset tetap. Rifka (2016) menyebutkan bahwa Capital intensity dapat diidentifikasikan sebagai perusahaan yang menginvestasikan asetnya pada aset tetap dan persediaan. UU No. 36 tahun 2008 tentang pajak penghasilan pasal 6 ayat 1 juga menyatakan bahwa besarnya penghasilan kena pajak ditetapkan melalui penghasilan bruto dikurangi biaya untuk mendapatkan, menagih dan memelihara penghasilan, dalam hal ini biaya depresiasi. Aset tetap yang besar maka akan mempunyai biaya depresiasi yang besar juga. Hal ini dapat berpengaruh terhadap tax avoidance karena biaya depresiasi dapat mengurangi penghasilan kena pajak perusahaan. Hal ini sejalan dengan penelitian Anindyka S et al. (2018) yang menyebutkan bahwa perusahaan yang memiliki aset tetap akan terdapat beban penyusutan atau beban depresiasi yang dapat menjadi pengurang laba sebelum pajak. Dengan demikian, dapat disimpulkan bahwa capital intensity berpengaruh positif terhadap tax avoidance. Hal ini didukung oleh penelitian Dharma \& Noviari (2017) dan Anindyka S, Pratomo, dan Kurnia (2018) menjelaskan bahwa semakin besar capital intensity perusahaan maka akan semakin besar tingkat tax avoidance perusahaan. Dengan penjelasan tersebut, peneliti menduga sementara bahwa capital intensity berpengaruh positif terhadap tax avoidance.

H2 : Capital Intensity secara parsial berpengaruh positif terhadap Tax Avoidance

\section{Pengaruh Kepemilikan Keluarga Terhadap Tax Avoidance}

Menurut Anderson Reeb (2003), menyatakan bahwa "Family firm (perusahaan keluarga) adalah setiap perusahaan yang memiliki pemegang saham dominan". Sebagai pemegang saham dominan, mereka dapat menentukan tujuan dan strategi perusahaan untuk mendapatkan laba yang lebih besar dengan menuntut manajemen untuk merealisasikan tujuan tersebut. Hal yang dilakukan manajemen untuk mencapai tujuan perusahaan yaitu menghasilkan laba yang maksimal dapat dilakukan dengan melakukan tax avoidance. Perusahaan dengan kepemilikan keluarga juga akan mendapatkan manfaat dari penghematan pembayaran pajak ketika melakukan tax avoidance. Hal ini sejalan dengan penelitian Indirawati \& Dwimulyani (2019) yang menyebutkan bahwa kepemilikan keluarga berpengaruh positif terhadap tax avoidance. Dengan demikian, dapat disimpulkan bahwa kepemilikan keluarga berpengaruh positif terhadap tax avoidance. Hal ini didukung oleh penelitian Praptidewi \& Sukartha (2016) dan Indirawati \& Dwimulyani (2019) membuktikan bahwa kepemilikan keluarga berpengaruh positif terhadap tax avoidance yang artinya semakin tinggi kepemilikan keluarga pada perusahaan maka semakin besar peluang perusahaan untuk melakukan tax avoidance.

H3 : Kepemilikan Keluarga secara parsial berpengaruh positif terhadap Tax Avoidance

Bedasarkan teori serta kerangka pemikiran yang telah dijelaskan, maka penelitian ini menghasilkan hipotesis, antara lain : (1) Karakter Eksekutif, Capital Intensity, dan Kepemilikan Keluarga secara simultan berpengaruh terhadap Tax Avoidance. (2) Karakter Eksekutif berpengaruh ke arah positif terhadap Tax Avoidance. (3) Capital Intensity berpengaruh ke arah positif terhadap Tax Avoidance. (4) Kepemilikan Keluarga berpengaruh ke arah positif terhadap Tax Avoidance.

\section{METODOLOGI PENELITIAN}


Penelitian ini menggunakan metode kuantitatif dengan populasi yang digunakan adalah perusahaan makanan dan minuman yang terdaftar di Bursa Efek Indonesia (BEI) periode 20142018. Teknik pengambilan sampel yang digunakan dalam penelitian ini adalah purposive sampling. Metode yang digunakan dalam penelitian ini adalah analisis statistik deskriptif dan analisis regresi data panel. Berikut merupakan rumus regresi data panel:

Keterangan :

$$
Y=\alpha+\beta_{1} X_{1}+\beta_{2} X_{2}+\beta_{3} X_{3}+\varepsilon
$$

Y : Tax Avoidance

a : Konstanta

$\mathrm{X}_{1} \quad$ : Karakter Eksekutif

$\mathrm{X}_{2} \quad$ : Capital Intensity

$\mathrm{X}_{3} \quad$ : Kepemilikan Keluarga

$\beta_{1}-\beta_{3}:$ Koefisien Regresi

$\varepsilon \quad:$ Error Term

\section{HASIL DAN PEMBAHASAN}

\section{Statistik Deskriptif}

Tabel 1 Hasil Pengujian Statistik Deskriptif Rasio

\begin{tabular}{cccc}
\hline & Capital Intensity & $\begin{array}{c}\text { Kepemilikan } \\
\text { Keluarga }\end{array}$ & $\begin{array}{c}\text { Cash Effective Tax } \\
\text { Rate }\end{array}$ \\
\hline Mean & 0.29143 & 0.51916 & 0.30020 \\
STDEV & 0.16400 & 0.24245 & 0.97688 \\
Maximum & 0.71987 & 0.87020 & 0.56442 \\
Minimum & 0.05510 & 0.17680 & 0.10870 \\
Observasi & 50 & 50 & 50 \\
\hline
\end{tabular}

Sumber: Data diolah, 2019

Tabel.1 menunjukkan bahwa nilai rata-rata pada capital intensity pada perusahaan makanan dan minuman sebesar 0.29143 , lebih besar dari standar deviasinya sebesar 0.16400 yang artinya capital intensity pada perusahaan makanan dan minuman memiliki data yang tidak bervariasi. Nilai maksimum capital intensity sebesar 0.71987 pada PT Nippon Sari Corporindo tahun 2014 dan nilai minimum capital intensity sebesar 0.05510 pada PT Delta Jakarta tahun 2018.

Rata-rata kepemilikan keluarga pada perusahaan makanan dan minuman sebesar 0.51916 , lebih besar dari standar deviasinya sebesar 0.24245 yang artinya kepemilikan keluarga pada perusahaan makanan dan minuman memiliki data yang tidak bervariasi. Nilai maksimum kepemilikan keluarga sebesar 0.87020 pada PT Wilmar Cahaya Indonesia tahun 2014-2018 dan nilai minimum kepemilikan keluarga sebesar 0.17680 pada PT Sekar Bumi tahun 2014-2016.

Rata-rata cash effective tax rate pada perusahaan makanan dan minuman sebesar 0.30020 , lebih kecil dari standar deviasinya sebesar 0.97688 yang artinya cash effective tax rate pada perusahaan makanan dan minuman memiliki data yang bervariasi. Nilai maksimum pada cash effective tax rate sebesar 0.56442 pada PT Sekar Laut tahun 2015 dan nilai minimum cash effective tax rate sebesar 0.10870 pada PT Nippon Sari Corporindo tahun 2018. 
Tabel 2 Hasil Pengujian Statistik Deskriptif Karakter Eksekutif (Nominal)

\begin{tabular}{lccc}
\hline & Risk Taker & Risk Averse & Total \\
\hline Jumlah Observasi & 17 & 33 & 50 \\
Persentase & $34 \%$ & $66 \%$ & $100 \%$ \\
\hline
\end{tabular}

Berdasarkan Tabel.2, dapat dilihat bahwa jumlah observasi yang mempunyai karakter sebagai risk taker sebanyak 17 (34\%) dan 33 (66\%) observasi mempunyai karakter sebagai risk averse. Dengan demikian mayoritas perusahaan makanan dan minuman yang sedang diteliti memiliki eksekutif dengan karakter risk averse atau penghindar resiko dimana pengambilan keputusan untuk mencapai tujuan perusahaan selalu menghindari resiko yang tinggi.

\section{Analisis Regresi Data Panel}

Tabel 3 Hasil Uji Model Fixed Effect

Dependent Variable: CETR

Method: Panel Least Squares

Date: 12/17/19 Time: 11:28

Sample: 20142018

Periods included: 5

Cross-sections included: 10

Total panel (balanced) observations: 50

\begin{tabular}{crrrr}
\hline \hline Variable & Coefficient & Std. Error & t-Statistic & Prob. \\
\hline \hline C & 0.616976 & 0.111148 & 5.550951 & 0.0000 \\
KE & -0.032221 & 0.039516 & -0.815387 & 0.4201 \\
Cl & 0.114243 & 0.054206 & 2.107561 & 0.0419 \\
KK & 0.187577 & 0.088964 & 2.108465 & 0.0418 \\
\hline \hline
\end{tabular}

Cross-section fixed (dummy variables)

\begin{tabular}{lrlr}
\hline \hline R-squared & 0.614634 & Mean dependent var & 0.300203 \\
Adjusted R-squared & 0.489650 & S.D. dependent var & 0.097688 \\
S.E. of regression & 0.069787 & Akaike info criterion & -2.267844 \\
Sum squared resid & 0.180198 & Schwarz criterion & -1.770718 \\
Log likelihood & 69.69610 & Hannan-Quinn criter. & -2.078536 \\
F-statistic & 4.917708 & Durbin-Watson stat & 2.585045 \\
Prob(F-statistic) & 0.000086 & & \\
\hline \hline
\end{tabular}

Sumber: Output Eviews 10, 2019

Berdasarkan tabel 4.10 maka dirumuskan persamaan model regresi data panel yang menjelaskan pengaruh karakter eksekutif, capital intensity, dan kepemilikan keluarga terhadap tax avoidance pada perusahaan subsektor makanan dan minuman periode 2014-2018 adalah: 


$$
Y=0.616976-0.032221 K E+0.114243 C I+0.187577 K K+e
$$

\section{Pengujian Hipotesis}

\section{Hasil Pengujian Hipotesis Secara Simultan (Uji F)}

Uji simultan (Uji F) pada dasarnya menunjukkan apakah semua variabel independen (karakter eksekutif, capital intensity, dan kepemilikan keluarga) secara bersama-sama atau simultan berpengaruh terhadap variabel dependen (tax avoidance) atau variabel terikat (Ghozali, 2018:98). Hasil uji simultan atau uji $F$ menggunakan data setelah ditransformasi logaritma natural. Berdasarkan tabel 3 nilai probabilitas secara simultan sebesar 0.000086 dimana nilai tersebut lebih kecil dari taraf signifikansi sebesar 0.05. Dapat disimpulkan bahwa Karakter Eksekutif, Capital Intensity, dan Kepemilikan Keluarga berpengaruh secara simultan terhadap Tax Avoidance.

\section{Hasil Pengujian Hipotesis Secara Parsial (Uji T)}

Uji T pada dasarnya menunjukkan seberapa jauh pengaruh satu variabel independen secara individual dalam menerangkan variasi variabel dependen (Ghozali, 2018:98). Berdasarkan tabel 4.12 hasil pengujian hipotesis secara parsial menunjukkan bahwa :

1. Variabel independen Karakter Eksekutif memiliki nilai probabilitas sebesar 0.4201 dimana nilai tersebut lebih besar dari taraf signifikansi yaitu sebesar 0.05 (5\%). Dapat disimpulkan bahwa variabel independen Karakter Eksekutif tidak berpengaruh terhadap Tax Avoidance secara parsial.

2. Variabel independen Capital Intensity memiliki nilai probabilitas sebesar 0.0419 dimana nilai tersebut lebih kecil dari taraf signifikansi yaitu sebesar 0.05 (5\%). Dapat disimpulkan bahwa variabel independen Capital Intensity berpengaruh dengan arah negatif terhadap Tax Avoidance secara parsial.

3. Variabel independen Kepemilikan Keluarga memiliki nilai probabilitas sebesar 0.0418 dimana nilai tersebut lebih kecil dari taraf signifikansi yaitu sebesar $0.05(5 \%)$. Dapat disimpulkan bahwa variabel independen Kepemilikan Keluarga berpengaruh dengan arah negatif terhadap Tax Avoidance secara parsial

\section{Pembahasan}

\section{Pengaruh Karakter Eksekutif Terhadap Tax Avoidance}

Koefisien regresi variabel karakter eksekutif memiliki nilai sebesar -0.032221 dengan tingkat signifikansi sebesar 0.4201 lebih besar dari 0.05. Dengan demikian karakter eksekutif tidak berpengaruh terhadap tax avoidance. Low (2006) menyebutkan eksekutif dengan karakter risk averse (penghindar resiko) cenderung tidak menyukai resiko sehingga dalam pengambilan keputusan selalu memilih dengan resiko yang lebih rendah. Karakter ini biasanya memiliki usia yang lebih tua, sudah lama memegang jabatan, dan memiliki ketergantungan terhadap perusahaan sehingga lebih mengutamakan keamanan daripada keuntungan yang memiliki resiko tinggi bagi perusahaan.

Hal ini didukung oleh tabel 4.5 pada statistik deskriptif yang menyatakan bahwa perusahaan makanan dan minuman memiliki eksekutif dengan karakter sebagai risk taker atau pengambil resiko sebanyak 17 sampel dari 50 sampel. Sedangkan eksekutif dengan karakter sebagai risk averse atau penghindar resiko memiliki sampel sebanyak 33 sampel dari 50 sampel yang artinya karakter risk averse lebih mendominasi daripada karakter risk taker. Data pada 
Lampiran 6 juga mendeskripsikan bahwa lebih banyak perusahaan yang membayarkan pajaknya daripada perusahaan yang terindikasi melakukan tax avoidance. Dapat disimpulkan bahwa eksekutif dengan karakter sebagai risk averse akan cenderung menghindari keputusankeputusan yang berisiko salah satunya dengan melakukan tax avoidance dan tidak termotivasi untuk melakukan hal tersebut untuk mendapatkan bonus. Hasil penelitian ini didukung oleh penelitian Kartana \& Wulandari (2018) yang menyatakan bahwa karakter eksekutif tidak berpengaruh terhadap tax avoidance.

\section{Pengaruh Capital Intensity Terhadap Tax Avoidance}

Koefisien regresi variabel capital intensity memiliki nilai sebesar 0.114243 dengan tingkat signifikansi sebesar 0.0419 lebih kecil dari 0.05 , artinya capital intensity berpengaruh positif terhadap cash effective tax rate dan dimana saat cash effective tax rate meningkat dapat diartikan tax avoidance menurun. Hal ini dapat disimpulkan bahwa capital intensity berpengaruh negatif terhadap tax avoidance. Aset tetap yang besar maka akan mempunyai biaya depresiasi yang besar juga. Tetapi, hasil penelitian menunjukkan bahwa besarnya investasi pada aset tetap perusahaan yang akan meningkatkan beban depresiasi tidak menunjukkan dampak yang besar dalam hal melakukan tax avoidance. biaya depresiasi bukan merupakan cara yang dilakukan oleh perusahaan makanan dan minuman untuk melakukan tax avoidance.

\section{Pengaruh Kepemilikan Keluarga Terhadap Tax Avoidance}

Koefisien regresi variabel kepemilikan keluarga memiliki nilai sebesar 0.187577 dengan tingkat signifikansi0020sebesar 0.0418 lebih kecil dari 0.05 , artinya kepemilikan keluarga berpengaruh positif terhadap cash effective tax rate dan dimana saat cash effective tax rate meningkat dapat diartikan tax avoidance menurun. Hal ini dapat disimpulkan bahwa kepemilikan keluarga berpengaruh negatif terhadap tax avoidance. Artinya semakin tinggi kepemilikan keluarga maka tax avoidance akan semakin menurun. Pemegang saham atau investor (principal) akan memiliki pengaruh yang besar dalam pengambilan keputusan perusahaan kedepannya sehingga praktik tax avoidance akan diminimalisir untuk menjaga nama baik perusahaan. Chen, Chen, Cheng, \& Shevlin (2010) menyebutkan bahwa perusahaan dengan kepemilikan keluarga akan lebih memilih untuk peduli terhadap sanksi dan kerusakan reputasi yang diakibatkan oleh tax avoidance. Hasil penelitian menunjukkan bahwa semakin besar kepemilikan keluarga pada perusahaan akan mengurangi tindakan tax avoidance

\section{Kesimpulan}

Berdasarkan analisis statistik deskriptif dapat diketahui bahwa variabel capital intensity dan kepemilikan keluarga pada perusahaan makanan dan minuman yang terdaftar di BEI periode 2014-2018 memiliki nilai rata-rata yang lebih tinggi dari standar deviasi yang berarti bahwa data sampel yang digunakan tidak bervariasi dan variabel tax avoidance memiliki nilai rata-rata yang lebih rendah dari standar deviasi yang berarti bahwa data sampel yang digunakan bervariasi. Berdasarkan analisis regresi data panel, menunjukkan bahwa secara simultan karakter eksekutif, capital intensity, dan kepemilikan keluarga berpengaruh terhadap tax avoidance. Secara parsial, karakter eksekutif tidak berpengaruh terhadap tax avoidance. Capital Intensity dan Kepemilikan Keluarga berpengaruh ke arah negatif terhadap tax avoidance. 


\section{DAFTAR PUSTAKA}

Alviyani, K. 2016. Pengaruh Corporate Governance, Karakter Eksekutif, Ukuran Perusahaan, Dan Leverage Terhadap Penghindaran Pajak. Jom Fekon, 3(Februari 2016).

Anderson, R., \& Reeb, D. 2003. Founding Family Ownership And Firm Performance: Evidence From The S\&P 500. Journal Of Finance, 58, 1301-1328.

Anindyka S, D., Pratomo, D., \& Kurnia. 2018. Pengaruh Leverage (Dar), Capital Intensity Dan Inventory Intensity Terhadap Tax Avoidance. E-Proceeding Of Management, 5(Maret 2018), 713.

Asfiyati. 2012. Pengaruh Corporate Governance, Kepemilikan Keluarga, Dan Karakteristik Perusahaan Terhadap Tax Avoidance. Universitas Sebelas Maret.

Chen, S., Chen, X., Cheng, Q., \& Shevlin, T. 2010. Are Family Firms More Tax Aggressive Than Non-Family Firms? \$. Journal Of Financial Economics, 95(1), 41-61. Https://Doi.Org/10.1016/J.Jfineco.2009.02.003

Dharma, N. B. S., \& Noviari, N. 2017. Pengaruh Corporate Social Responsibility Dan Capital Intensity Terhadap Tax Avoidance. E-Jurnal Akuntansi Universitas Udayana, 18(Januari 2017), 529-556.

Indirawati, T., \& Dwimulyani, S. 2019. Pengaruh Kepemilikan Keluarga Dan Leverage Terhadap Tax Avoidance Dengan Menggunakan Strategi Bisnis Sebagai Variabel Moderasi. Prosiding Seminar Nasional Pakar Ke 2.

Kartana, I. W., \& Wulandari, N. A. S. 2018. Pengaruh Karakter Eksekutif, Karakteristik Perusahaan Dan Corporate Governance Terhadap Tax Avoidance. Jurnal Krisna: Kumpulan Riset Akuntansi, 10 (1 Juli 2018).

Low, A. 2006. Managerial Risk Taking Behavior And Equity Based Compensation. Fisher College Of Business Working Paper, 03(003).

Nengsih, H., Suryani, E., \& Kurnia. 2018. Pengaruh Karakter Eksekutif, Profitabilitas Dan Ukuran Perusahaan Terhadap Tax Avoidance (Studi Pada Perusahaan Manufaktur Subsektor Consumer Goods Yang Terdaftar Di Bursa Efek Indonesia Tahun 2012 - 2016). EProceeding Of Management, 5.

Oktamawati, M. 2017. Pengaruh Karakter Eksekutif, Komite Audit, Ukuran Perusahaan, Leverage, Pertumbuhan Penjualan, Dan Profitabilitas Terhadap Tax Avoidance. Jurnal Akuntansi Bisnis, 15 (Maret 2017).

Paligorova, T. 2010. Corporate Risk Taking And Ownership Structure Corporate Risk Taking And Ownership.

Pohan, C. A. 2016. Manajemen Perpajakan (Revisi 201). Jakarta: Gramedia Pustaka Utama.

Praptidewi, L. P. M., \& Sukartha, I. M. 2016. Pengaruh Karakteristik Eksekutif Dan Kepemilikan Keluarga Pada Tax Avoidance Perusahaan. E-Jurnal Akuntansi Universitas Udayana, 17(Oktober 2016), 426-452.

Siregar, Rifka, \& Widyawati, D. 2016. Pengaruh Karakteristik Perusahaan Terhadap Penghindaran Pajak Pada Perusahaan Manufaktur Di Bei. Jurnal IImu Dan Riset Akuntansi, 5 . 
Swingly, C., \& Sukartha, I. M. 2015. Pengaruh Karakter Eksekutif, Komite Audit, Ukuran Perusahaan, Leverage Dan Sales Growth Pada Tax Avoidance Fakultas Ekonomi Dan Bisnis Universitas Udayana, Bali, Indonesia Fakultas Ekonomi Dan Bisnis Universitas Udayana , Bali , Indonesia Dari Uraian. E-Jurnal Akuntansi Universitas Udayana, 10, 47-62. 